\title{
Identification of a filamin isoform enriched at the ends of stress fibers in
}

\section{chicken embryo fibroblasts}

\author{
FREDRICK M. PAVALKO*, CAROL A. OTEY and KEITH BURRIDGE \\ Department of Cell Biology and Anatomy, University of North Carolina at Chapel Hill, Chapel Hill, NC 27599, USA
}

* Author for correspondence

\begin{abstract}
Summary
Filamin (actin-binding protein) is a cytoskeletal protein that crosslinks actin filaments in vitro. Filamin is thought to be involved in a variety of cell types in stabilizing actin networks, and in platelets it may play a role in linking actin to the membrane. In this report, we describe a monoclonal antibody (Mab 6E) that was used to immunoprecipitate an isoform of filamin from extracts of chicken fibroblasts. Immunofluorescence staining of chicken fibroblasts revealed an unusual pattern: while other filamin antibodies stained the entire length of stress fibers, the Mab 6E staining was predominantly at the ends of stress fibers. In double-labeling experiments, the distribution of the Mab $6 \mathrm{E}$ antigen was found to be strikingly similar to that of $\alpha$-actinin.

apparently not localized evenly throughout the entire area of adhesion, being absent from or greatly reduced in the distal portion of the area.

The Mab $6 \mathrm{E}$ antigen was identified as filamin by immunological crossreactivity with a panel of antifilamin monoclonals as well as with a polyclonal anti-filamin. The Mab $6 \mathrm{E}$ isoform, however, was found to differ from the major form of filamin both by one-dimensional peptide analysis and slightly slower migration on SDS-containing gels. The Mab $6 \mathrm{E}$ antigen was also detected by immunofluorescence in the $Z$-lines of isolated adult myofibrils. These results suggest that chicken fibroblasts may express different isoforms of filamin that could have specialized roles within the cell.
\end{abstract} Mab $6 \mathrm{E}$ staining was associated, in part, with focal adhesions, which are sites of actin-membrane attachment. Unlike other focal adhesion proteins, such as vinculin and talin, this filamin isoform is

Key words: filamin, soform, stress fiber, fibroblast.

\section{Introduction}

Bundles of actin filaments, known as stress fibers, terminate at the cytoplasmic face of the plasma membrane in cultured non-muscle cells at specialized sites termed focal adhesions (reviewed by Burridge et al. 1988). The linkage between actin and the membrane at focal adhesions is thought to involve several cytoskeletal proteins that are concentrated in these sites, including $\alpha$-actinin (Lazarides and Burridge, 1975), which binds actin directly (Maruyama and Ebashi, 1965; Burridge and Feramisco, 1981), vinculin (Geiger, 1979), which binds to $\alpha$-actinin (Otto, 1983; Wilkins et al. 1983; Burridge and Mangeat, 1984; Wachsstock et al. 1987), and the protein talin (Burridge and Connell, 1983), which interacts with both vinculin (Burridge and Mangeat, 1984) and the transmembrane fibronectin receptor, integrin (Horwitz et al. 1986).

Filamin is an actin-binding protein that dimerizes to cross-link actin filaments. Filamin, also called actinbinding protein in macrophages (Hartwig and Stossel,
1975) and platelets (Lucas et al. 1976), was isolated from avian smooth muscle (Wang et al. 1975) and a group of homologous proteins have since been purified from several non-muscle sources (Weihing, 1983; Mangeat and Burridge, 1983; Stossel et al. 1985; Hock and Condeelis, 1987). In some immunofluorescence studies, filamin has been described as distributed continuously along the length of the stress fibers (Wang et al. 1975; Heggeness et al. 1977; Webster et al. 1978; Gordon and Bushnell, 1979; Langanger et al. 1984), but in other cases it has occasionally been detected with a periodic distribution (Osborn and Weber, 1979; Rathke et al. 1979). The differences here may, in part, reflect different cell types. Generally, in chicken embryo fibroblasts, at the level of light microscopy, a continuous distribution has been noted in contrast to the situation in mammalian cells where the periodicity has often been observed. A lessregular pattern is frequently observed for other cytoskeletal proteins such as $\alpha$-actinin and tropomyosin in chicken fibroblasts compared with the more 'sarcomeric' pattern seen in mammalian fibroblasts (Lazarides, 1975; 
Lazarides and Burridge, 1975; Gordon, 1978; Zigmond et al. 1979; Sanger et al. 1983).

In platelets, it has been shown that filamin (actinbinding protein, $\mathrm{ABP}$ ), participates in linking actin to a membrane glycoprotein (Fox, 1985; Okita et al. 1985; Ezzell et al. 1988). It appears, though, that only a subset of the filamin in platelets may be involved in this linkage. It is not known if filamin plays a similar role in other types of cells. Two forms of filamin have been found in HeLa cells (Mangeat and Burridge, 1983) but it is not clear if these proteins have distinct functions. The existence of developmentally regulated filamin isoforms during skeletal myogenesis has been demonstrated previously (Gomer and Lazarides, 1983a,b). Also, partial peptide mapping of filamin from several non-muscle sources suggests that cell type-specific forms of this protein exist (Davies et al. 1978; Wallach et al. 1978; Weihing, 1983).

We describe here a monoclonal antibody (Mab 6E) that, by immunofluorescence microscopy, predominantly labels the ends of stress fibers in cultured chicken fibroblasts. This antibody recognizes a single high molecular weight protein that migrates slightly more slowly than chicken gizzard filamin by SDS-gel electrophoresis. Several monoclonal antibodies specific for filamin, as well as a polyclonal rabbit anti-filamin antibody, cross-react with the protein immunoprecipitated by Mab $6 \mathrm{E}$, demonstrating homology between this protein and filamin. Additionally, partial peptide mapping of the Mab 6E antigen and filamin revealed that these proteins are similar, but not identical. The unique localization of a filamin isoform at stress fiber ends in cultured nonmuscle cells raises the possibility that this protein may play a role in the organization or attachment of actin to the cytoplasmic face of the membrane.

\section{Materials and methods}

\section{Monoclonal antibody production}

An extract of chicken gizzard, obtained as previously described (Feramisco and Burridge, 1980), was passed over an F-actin affinity column prepared by the method of Miller et al. (1985). After extensively washing the column with buffer, specifically bound proteins were eluted with $0.25 \mathrm{M}-\mathrm{NaCl}$. F-actin binding proteins were concentrated by ammonum sulfate precipitation and dialysed against PBS. Balb/c mice were immunızed with $50 \mu \mathrm{l}$ of this crude mixture of $\mathrm{F}$-actın binding proteins by intrasplenic injection and were then boosted 3 weeks later with an additional $50 \mu \mathrm{l}$ of the same mixture. After 3 days, fusion of mouse spleen cells was performed with NS-1 myeloma cell partners. After 10-12 days, hybridoma culture supernatants were screened by immunofluorescence on both methanol- and formaldehyde-fixed chicken embryo fibroblasts (CEF). The hybridoma described in this report, Mab 6E, was subcloned three times by the limiting dilution series method. Mab $6 \mathrm{E}$ culture supernatant was concentrated tenfold by ammonium sulphate precipitation before use. Concentrated Mab $6 \mathrm{E}$ was used undiluted for immunoprecipitation and diluted 1:2 with PBS for immunofluorescence experiments.

\section{Cell culture and preparation of myofibrils}

Primary fibroblast cultures were prepared by trypsinization of skin from 8- to 10-day-old chicken embryos. Cells were grown in Dulbecco's Modified Eagle's medium (DMEM; Gibco, Grand Island, NY) containing $10 \%$ fetal calf serum (Gibco), 50 units $\mathrm{ml}^{-1}$ pencillin and $50 \mu \mathrm{g} \mathrm{ml}^{-1}$ streptomycin at $37^{\circ} \mathrm{C}$ in $5 \% \mathrm{CO}_{2}$ and passaged every $2-4$ days. Chicken embryonic myoblasts were obtained as described previously (Gomer and Lazarides, 1981). Myofibrils were obtained from adult chicken skeletal muscle according to the method of Gomer and Lazarides $(1983 a)$ and stored in $50 \%$ glycerol at $-20^{\circ} \mathrm{C}$.

\section{Fluorescence microscopy}

Cells for immunofluorescence were grown on glass coverslips for $24-48 \mathrm{~h}$ prior to use in medium containing $10 \%$ fetal calf serum. Cells were fixed in $1.8 \%$ formaldehyde $(v / v)$ in phosphate-buffered saline (PBS, $\mathrm{pH} \mathrm{7.4)} \mathrm{for} 10 \mathrm{~min}$. They were then washed in Tris-buffered saline (TBS: $150 \mathrm{~mm}-\mathrm{NaCl}$, $50 \mathrm{~mm}$-Tris- $\mathrm{HCl}, \mathrm{pH} 7 \cdot 4,0.1 \% \mathrm{NaN}_{3}$ ) for $5 \mathrm{~min}$ followed by permeabilization with $0.2 \%(\mathrm{v} / \mathrm{v})$ Triton X-100 in TBS for $2 \mathrm{~min}$, then washed for an additional $5 \mathrm{~min}$ in fresh TBS. Myofibrils were adsorbed to gelatin-coated glass coverslips and fixed in ice-cold methanol for $10 \mathrm{~min}$, then washed in TBS for $5 \mathrm{~min}$. Cells or myofibrils were incubated in primary antibody diluted in TBS for $1 \mathrm{~h}$ at $37^{\circ} \mathrm{C}$. Excess antibody was removed by washing three times, for 5 min each, in TBS. The cells were then incubated with the appropriate second antibody, which was conjugated to either fluorescein or rhodamine (obtained from Jackson Immunoresearch Labs), for $1 \mathrm{~h}$ at $37^{\circ} \mathrm{C}$. Rhodamine-conjugated phalloidin (Molecular Probes, Inc., Eugene, OR) was used at a dilution of $1: 300$. The coverslips were washed three times, for $5 \mathrm{~min}$ each, in TBS, then rinsed briefly in deionized water and mounted in Gelvatol (Monsanto). The cells were observed using a Zeiss IM-35 photomicroscope with a $\times 63$ oil immersion objective and photographed with T-Max 400 film (Kodak). One monoclonal antibody to filamin that was used for immunofluorescence was purchased from Sigma (St Louis, MO), and three others were generously provided by $\mathrm{Dr}_{\mathrm{r}}$ Jim Lin (Univ. of Iowa). Rabbit polyclonal antibodies against $\alpha$-actinin, tropomyosin, talin and filamin were raised against purified chicken proteins. Interference-reflection microscopy was performed as described by Izzard and Lochner (1976) using a Zeiss Antiflex $\times 63$ objective and photographed using Tech Pan 2415 film.

\section{Immunoprecipitation, SDS-gel electrophoresis and antigen quantification}

Chicken embryo fibroblasts were metabolically labelled by incubation in methionine-free DMEM containing $50 \mu \mathrm{Ci} \mathrm{ml}^{-1}$ of $\left.{ }^{35} \mathrm{~S}\right]$ methionine (Amersham, Arlington Heights, IL) and supplemented with $10 \%$ DMEM-H, $10 \%$ fetal calf serum and glutamine, for $18 \mathrm{~h}$ at $37^{\circ} \mathrm{C}$ in $5 \% \mathrm{CO}_{2}$. At the end of the labelling period, the cells were washed three times with Hank's Buffered Saline Solution and extracts were prepared by lysis in TBS, pH 7.2, containing $1 \%$ Triton $\mathrm{X}-100,1 \%$ deoxycholate, $10 \mu \mathrm{m}$-leupeptin and $10 \mu \mathrm{m}$-phenylmethylsulfonyl fluoride (PMSF) at $4^{\circ} \mathrm{C}$ for $5 \mathrm{~min}$. The lysates were centrifuged at $10000 \mathrm{~g}$ and the supernatant was precleared with $100 \mu \mathrm{l}$ of a $10 \%(\mathrm{w} / \mathrm{v}$ ) suspension of Staphylococcus A cells (Pansorbin, Calbiochem, San Diego, CA). The Staphylococcus A suspension was sedimented and an excess of either Mab 6E or monoclonal anti-filamin antibody (Sigma) was added to the supernatant and then incubated for $1 \mathrm{~h}$ at $4^{\circ} \mathrm{C}$. A $100 \mu$ sample of a $10 \%(\mathrm{w} / \mathrm{v})$ suspension of protein A-Sepharose (Pharmacia, Piscataway, NJ) that had been coupled to affinity-purified goat anti-mouse Ig (Cappel Laboratories, Cochranville, PA) was added to the mixture, which was incubated for an additional $1 \mathrm{~h}$ at $4^{\circ} \mathrm{C}$ (unconjugated protein $\mathrm{A}$-Sepharose was used for immunoprecipitation with polyclonal rabbit anti- 
filamin). The complexes containing bound antigen were pelleted and washed four times with lysis buffer. A $15 \mu l$ portion of gel sample buffer was added to the final pellet, which was boiled for $5 \mathrm{~min}$ to release bound antigen.

Samples were electrophoresed on $10 \%$ SDS-polyacrylamide gels according to the method of Laemmli (1970) except that the bisacrylamide concentration was $0.13 \%$. Following fixation in $7.5 \%$ acetic acid $10 \%$ methanol for $15 \mathrm{~min}$, the gels were treated with Amplify (Amersham) for $30 \mathrm{~min}$ before they were dried and exposed to XAR-5 film (Kodak) at $-70^{\circ} \mathrm{C}$.

Quantification of antigen was carried out by excising the $\left[{ }^{35} \mathrm{~S}\right]$ methionine-labelled protein from a CEF extract that had been immunoprecipitated with either polyclonal anti-filamin antibody or Mab 6E from Coomassie Blue-stained gels. The radioactivity in each gel slice was determined by counting in liquid scintillant using a Beckman LS5000 LE Beta Spectrometer. The average background radioactivity was determined from protein-free gel slices that were excised from each lane. To ensure that all the antigen in the extracts was precipitated, each sample was subjected to two rounds of immunoprecipitation.

\section{Immunoblotting}

Immunoblot analysis was performed by a modification of the method of Towbin et al. (1979). Proteins resolved by SDS-PAGE were transferred to nitrocellulose (NC) and incubated for $1 \mathrm{~h}$ in TBS containing $2.5 \%$ bovine serum albumin (BSA), $0.2 \%$ gelatin, and $0.05 \%$ Tween 20 . The nitrocellulose strips were then incubated for $1 \mathrm{~h}$ in primary antibody (mouse monoclonal anti-filamin antibodies were diluted 1:1500; rabbit polyclonal anti-filamin was diluted 1:2000 in the buffer described above). After washing for $1 \mathrm{~h}$ in TBS containing $0.2 \%$ gelatin and $0.05 \%$ Tween 20 , the $\mathrm{NC}$ was incubated in horseradish peroxidase-conjugated anti-mouse or anti-rabbit IgG (Jannsen, Piscataway, NJ), diluted 1:1000 for $1 \mathrm{~h}$ then washed for an additional $1 \mathrm{~h}$. Visualization was obtained by treating the blot with $0.03 \%$ 4-chloro-1-naphthol, $0.005 \%$ $\mathrm{H}_{2} \mathrm{O}_{2}$ in TBS.

\section{Peptide mapping}

Samples for peptide mapping were immunoprecipitated from $\left[{ }^{35} \mathrm{~S}\right]$ methionine-labelled chicken embryo fibroblasts, using either Mab $6 \mathrm{E}$ or an anti-filamin monoclonal antibody, and separated by SDS-gel electrophoresis as described above, except that the gels were dried unfixed and without treatment in Amplify (Amersham). Radiolabelled bands were identified and excised from the dried gels and the gel slices were rehydrated directly in the wells of a $15 \%$ SDS-polyacrylamide gel. The proteins were subjected to proteolysis directly in the stacking buffer and gel as described by Cleveland (1983). Briefly, the gel slices were overlaid with $1.0 \mathrm{\mu g}$ of protease (V8 protease or TPCK-treated trypsin, both from Sigma) in overlay buffer (Cleveland, 1983) and allowed to rehydrate for $15 \mathrm{~min}$ before beginning the electrophoresis. Samples were then run at approximately $80 \mathrm{~V}$ through the stacking gel so that the total time of exposure to the enzyme before reaching the resolving gel was $1 \mathrm{~h}$. The gels were then fixed, treated with Amplify and exposed to XAR-5 film as described above.

\section{Results}

We wanted to identify additional proteins that are associated with actin or focal adhesions and that could potentially play a structural or regulatory role in mediating the attachment of actin to the membrane. To this end, we generated monoclonal antibodies against a crude mixture of $\mathrm{F}$-actin-binding proteins isolated from chicken gizzard. Hybridoma supernatants were screened by immunofluorescence, and one clone, designated 6E (Mab 6E), was chosen for further study due to its unusual staining pattern (described in detail below).

\section{Immunoprecipitation using $M a b 6 E$}

A detergent extract from metabolically labelled chicken embryo fibroblasts was subjected to immunoprecipitation using culture supernatant from clone $\mathrm{Mab} 6 \mathrm{E}$. This antibody precipitated a single high molecular weight protein of approximately $270000 M_{\mathrm{r}}$ (Figure 1 , lane 4 ), which migrated near the position of purified chicken gizzard filamin (not shown).

When Mab 6E was used to immunoprecipitate protein from an extract of chicken gizzard that was enriched for filamin, immunostaining of the precipitated antigen with any of four monoclonal antibodies or a polyclonal antibody against filamin revealed that the immunoprecipitate was antigenically related to filamin (Figure 2 ). The protein precipitated by $\mathrm{Mab} 6 \mathrm{E}$ and recognized by the polyclonal and monoclonal antibodies against filamin migrated slightly slower than the filamin band on SDS-gels. Mab 6E did not recognize SDS-denatured protein from either a CEF extract or a chicken gizzard

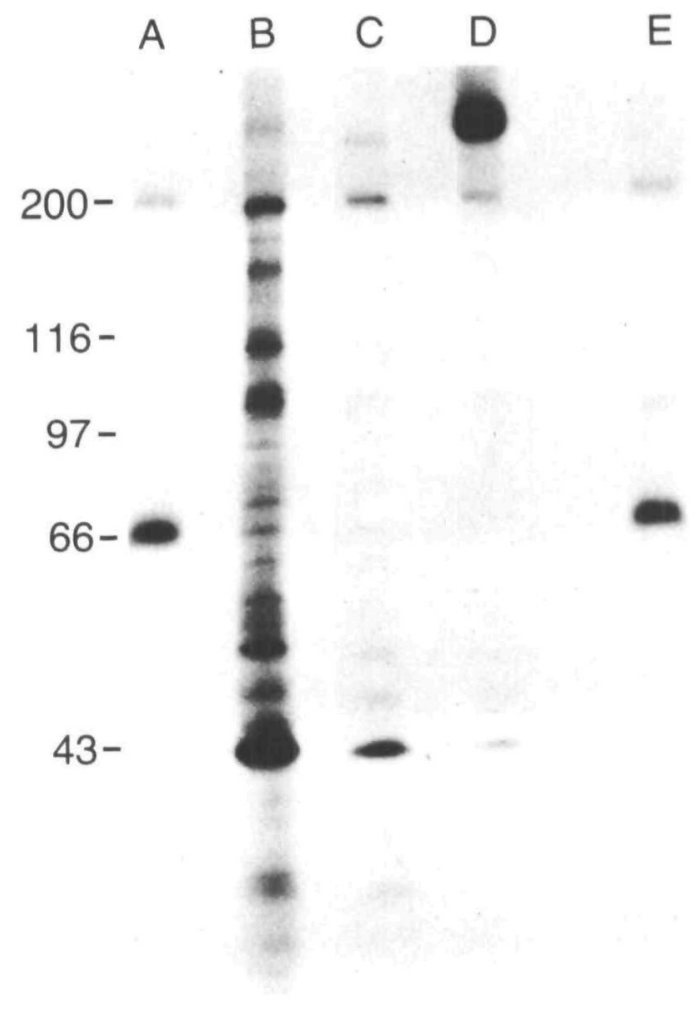

Fig. 1. Immunoprecipitation from $\left[{ }^{35} \mathrm{~S}\right]$ methionine-labelled chicken embryo fibroblasts using Mab $6 \mathrm{E}$. Lanes $\mathrm{A}$ and $\mathrm{E}$, ${ }^{125} \mathrm{I}$-labelled molecular weight markers $\left(M_{\mathrm{r}} \times 10^{-3}\right)$. Lane $\mathrm{B}$, total $\left[{ }^{35} \mathrm{~S}\right]$ methionine-labelled protein from chicken embryo fibroblasts. Lane $\mathrm{C}$, control immunoprecipitate using hybridoma culture media. Lane D, immunoprecipitate using Mab 6E. 


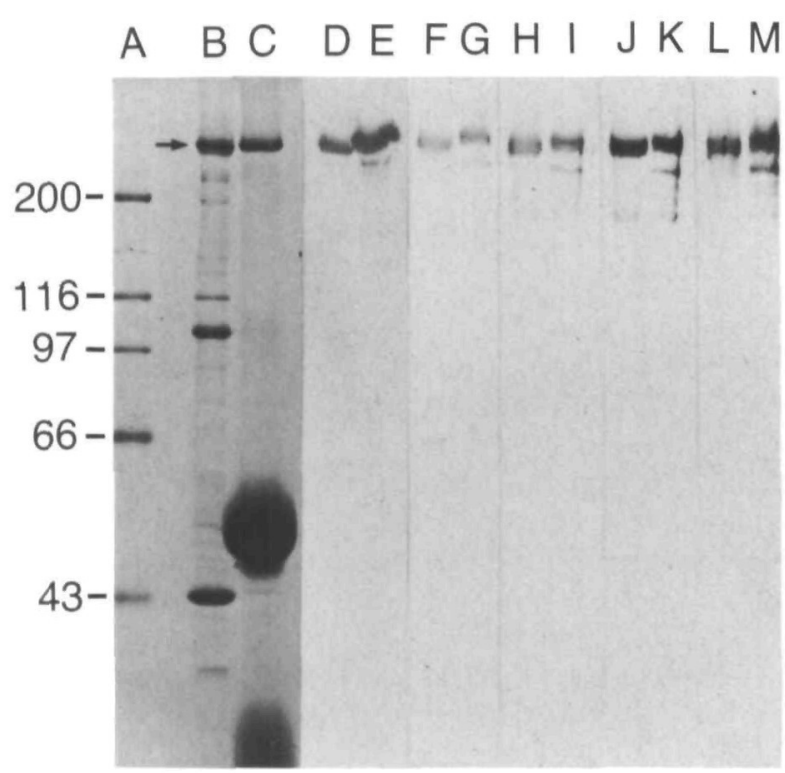

Fig. 2. Immunoblots of Mab 6E-immunoprecipitated protein and chicken gizzard extract using different anti-filamin antibodies. Lane $A,{ }^{125}$ I-labelled molecular weight markers $\left(M_{\mathrm{r}} \times 10^{-3}\right)$. Lanes $\mathrm{B}, \mathrm{D}, \mathrm{F}, \mathrm{H}, \mathrm{J}$ and $\mathrm{L}$, chicken gizzard extract (arrow). Lanes $\mathrm{C}, \mathrm{E}, \mathrm{G}, \mathrm{I}, \mathrm{K}$ and $\mathrm{M}$, immunoprecipitate from chicken gizzard extract using Mab 6E. In Lanes $B$ and $C$ the gel was stained with Coomassie Blue. Lanes D-M are immunoblots using either a rabbit anti-filamin antibody $(\mathrm{D}, \mathrm{E})$, or one of four different monoclonal anti-filamin antibodies (F,G: JLN10), (H,I: JLN17), (J,K: JLN21), (L,M: purchased from Sigma).

extract and therefore could not be used for immunoblotting following gel electrophoresis.

\section{Immunofluorescence microscopy}

Immunofluorescence microscopy using Mab $6 \mathrm{E}$ revealed that this antibody labelled the ends of stress fibers in cultured chicken embryo fibroblasts. As can be seen in Figure $3 \mathrm{~A}, \mathrm{~B}, \mathrm{Mab} 6 \mathrm{E}$ staining was very bright at the ends of the rhodamine-phalloidin-labelled stress fibers that terminated either at the cell periphery or in the interior of the cell. Mab $6 \mathrm{E}$ staining was faint or sparse along the central portions of the stress fibers. Occasionally, slight periodic staining was seen between stress fibers but membrane ruffles were never stained using Mab 6E. This pattern is different from that normally seen for filamin, as shown in Figure 3C-F. When chicken embryo fibroblasts were labelled with a polyclonal rabbit anti-filamin antibody (Figure 3D) or a monoclonal antibody directed against filamin (Figure 3F), the stress fibers were uniformly labelled along their entire length. Additionally, three other anti-filamin monoclonal antibodies stained fibroblasts in a pattern identical to that seen in Figure $3 \mathrm{~F}$ (data not shown).

In most mammalian cell types, antibodies against tropomyosin and $\alpha$-actinin label the stress fibers in a clearly periodic pattern (Lazarides, 1975; Lazarides and Burridge, 1975; Osborn and Weber, 1979). In chicken cells, however, the periodicity of $\alpha$-actinin and tropomyosin is often less discernible. We examined the distribution of the antigen recognized by $\mathrm{Mab} 6 \mathrm{E}$ relative to the distribution of these actin binding proteins by double-labelling chicken embryo fibroblasts with Mab $6 \mathrm{E}$ and polyclonal antibodies against filamin, tropomyosin or $\alpha$-actinin. A direct comparison of polyclonal anti-filamin staining and Mab $6 \mathrm{E}$ staining is shown in Figure $4 \mathrm{~A}, \mathrm{~B}$, confirming that the anti-filamin polyclonal antibody labels the entire stress fiber, including the region labelled with Mab 6E. In contrast, an antibody against tropomyosin labelled the entire length of the stress fiber but the staining was diminished and somewhat periodic at stress fiber ends, whereas Mab $6 \mathrm{E}$ staining was very bright at the ends of stress fibers (Figure 4C,D). Comparing the staining of $\mathrm{Mab} 6 \mathrm{E}$ with the staining for $\alpha$-actinin, we found the patterns to be strikingly similar. As shown in Figure $4 \mathrm{E}, \mathrm{F}$, both $\mathrm{Mab} 6 \mathrm{E}$ and $\alpha$-actinin stained most brightly at the ends of the stress fibers. In addition, $\alpha$-actinin was often detected in a periodic pattern between the stress fibers.

We wanted to know if the Mab $6 \mathrm{E}$ antigen was also present in focal adhesions. For these experiments, we labelled cells with Mab $6 \mathrm{E}$ and compared the Mab $6 \mathrm{E}$ staining pattern to the distribution of focal adhesions, as identified by both interference reflection microscopy and staining with antibody against the focal adhesion protein talin. Figure 5A,B shows that the termini of stress fibers labelled with rhodamine-phalloidin fill the entire focal adhesion as defined by staining with antibodies against talin. Mab 6E staining, however, is associated in part with focal adhesions (Figure $5 \mathrm{C}-\mathrm{F}$ ) but does not extend to the distal end of the focal adhesion, nor does it appear to occupy the entire area of the adhesion. We also found that $\alpha$-actinin staining did not occupy the entire area of the focal adhesion in these chicken cells. Again, this is in contrast to the situation in mammalian cells in which $\alpha$-actinin staining is found more prominently in focal adhesions (Wehland et al. 1979).

Previous studies have demonstrated that filamin is also expressed in skeletal muscle (Bechtel, 1979; Gomer and Lazarides, 1981) and that distinct isoforms of filamin exist in muscle and non-muscle cells (Gomer and Lazarides, 1983a). In order to determine if the filamin recognized by Mab $6 \mathrm{E}$ was a non-muscle-specific form, we used this antibody to stain cultured chicken myoblasts and isolated adult myofibrils. When chicken myoblasts were labelled with $\mathrm{Mab} 6 \mathrm{E}$ the staining pattern was identical to that seen in fibroblasts (not shown). However, Mab $6 \mathrm{E}$ also labelled the $\mathrm{Z}$-lines of adult chicken myofibrils (Figure 6), demonstrating that expression of the Mab $6 \mathrm{E}$ antigen is not restricted to non-muscle cells. We did not, however, find any detectable Mab $6 \mathrm{E}$ staining in chicken cardiac myocytes, nor did the antibody label a variety of cultured mammalian fibroblasts including those from rat, monkey and human.

\section{Partial peptide mapping of the Mab $6 E$ antigen}

Because Mab 6E recognized a protein that was antigenically related to filamin but was distributed in cells in a pattern distinct from that obtained using other antifilamin antibodies, and because this protein migrated slightly more slowly than gizzard filamin, we wanted to know if Mab $6 \mathrm{E}$ might be recognizing an isoform of 
filamin. In order to determine the degree of homology between the Mab $6 \mathrm{E}$ antigen and authentic filamin, we compared partial peptide maps obtained by proteolytic digestion of the samples as described by Cleveland (1983). The $\left[{ }^{35} \mathrm{~S}\right]$ methionine-labelled proteins immunoprecipitated by either Mab $6 \mathrm{E}$ or a commercially available
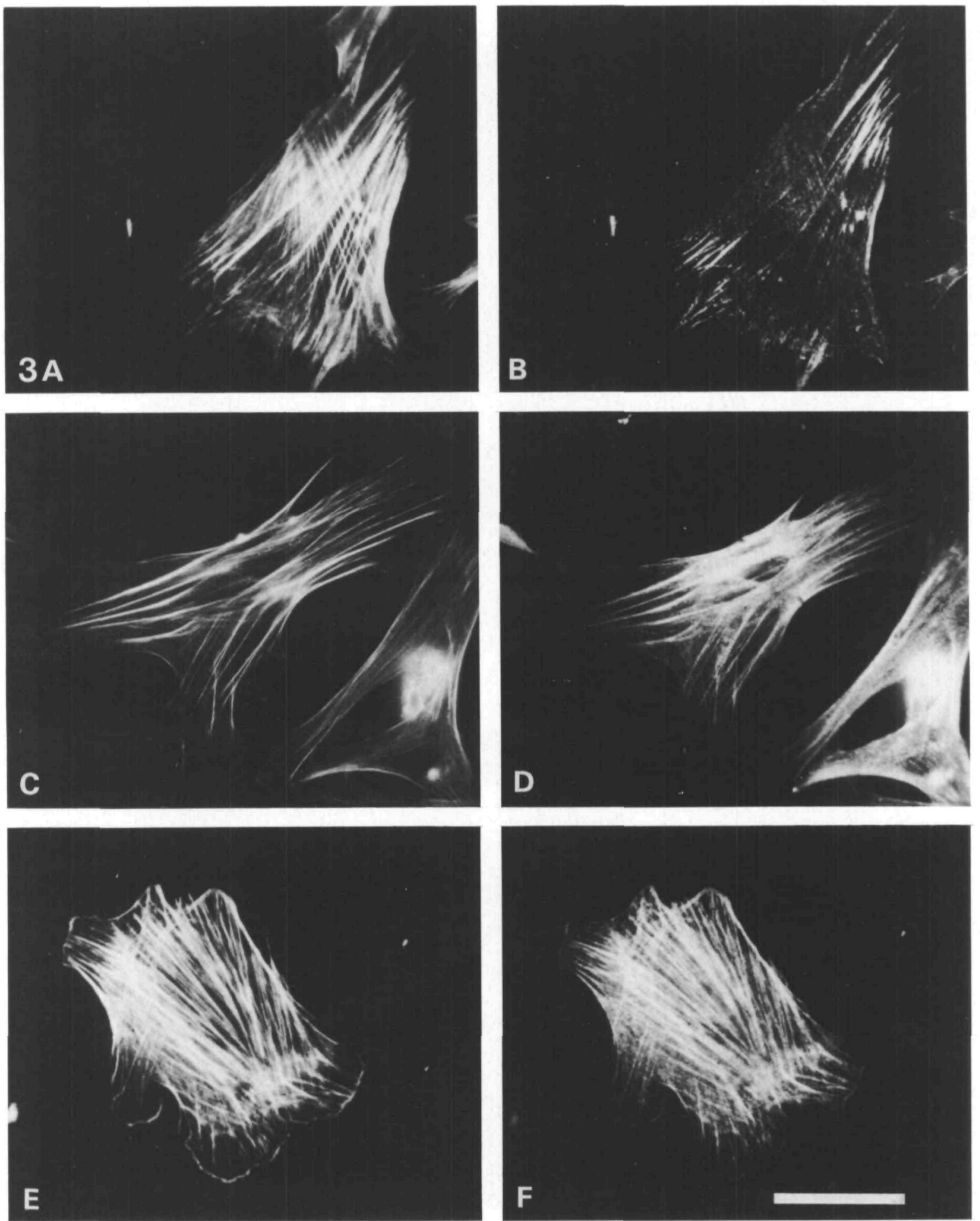

Fig. 3. Immunofluorescence staining of formaldehyde-fixed chicken embryo fibroblasts. Cells were double-labelled with rhodamine-phalloidin to visualize filamentous actın $(\mathrm{A}, \mathrm{C}, \mathrm{E})$ and in the corresponding images with Mab 6E (B), polyclonal antifilamin (D), or monoclonal anti-filamin purchased from Sigma (F). Bar, $20 \mu \mathrm{m}$. 

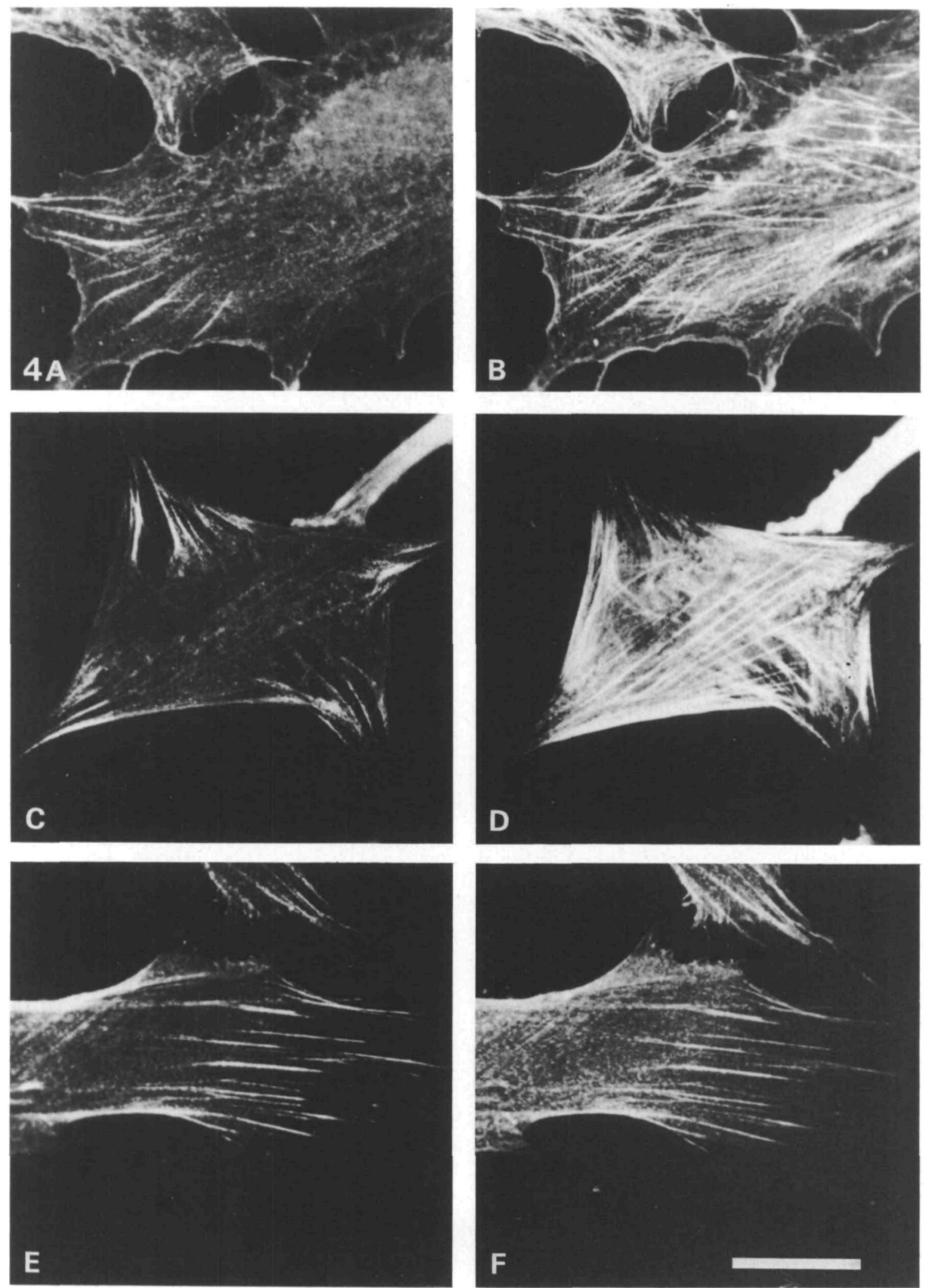

Fig. 4. Double-immunofluorescence staining of formaldehyde-fixed chicken embryo fibroblasts. Cells were double-labelled with Mab 6E (A,C,E) and with polyclonal antibodies specific for filamin (B), tropomyosin (D), or a-actinin (F). Note the similar distribution of Mab $6 \mathrm{E}$ antigen (E) and $\alpha$-actınin (F). Bar, $20 \mu \mathrm{m}$. 
trypsin yielded many identical peptides, thus confirming that the two proteins are related. However, both proteases reproducibly generated some unique peptides, as seen in Figure 7. This demonstrates that these two proteins are not identical and suggests that the Mab $6 \mathrm{E}$ antigen is an isoform of filamin.

To estimate the percentage of total filamin that is represented by this isoform, we compared immuno-
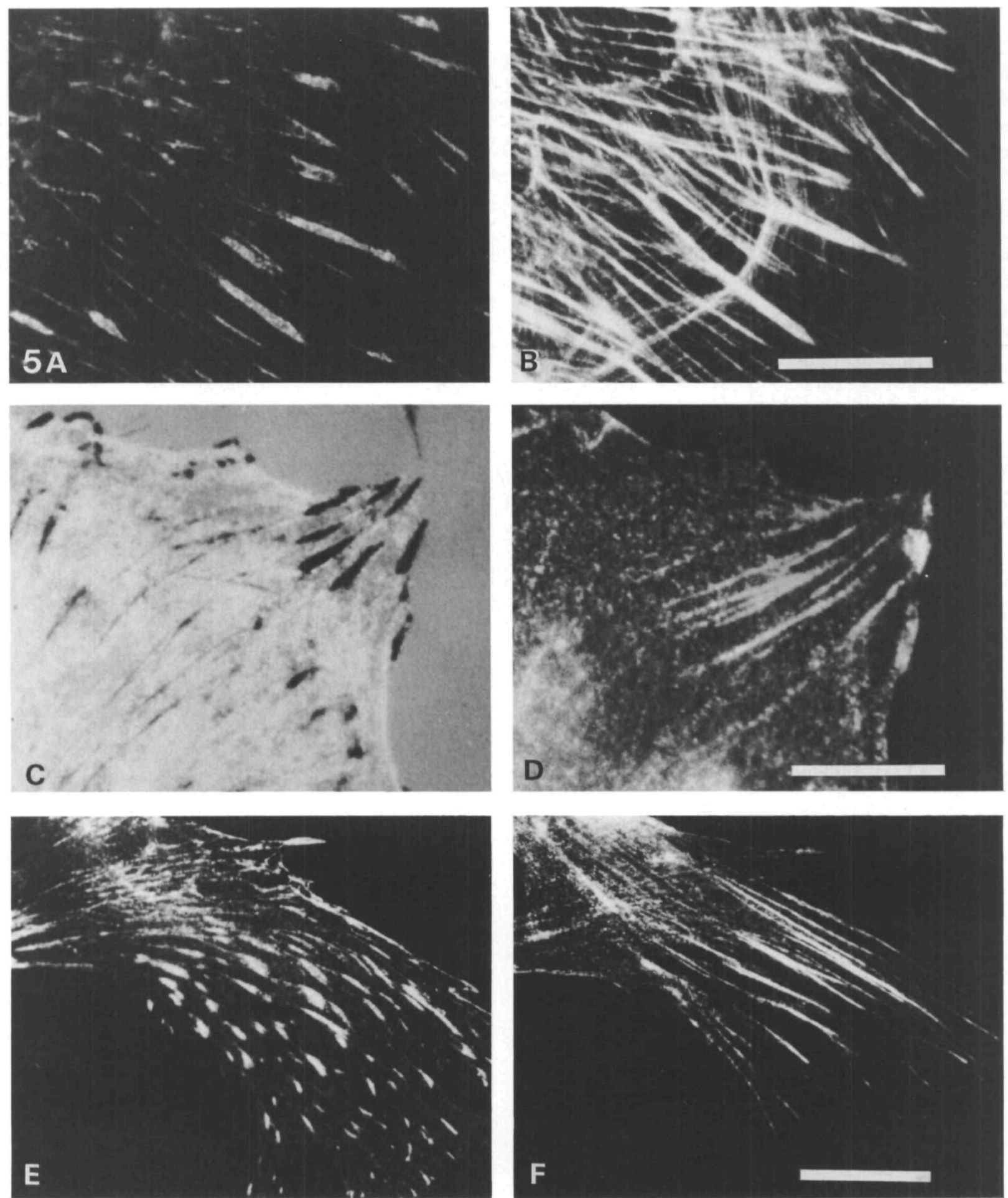

Fig. 5. Localization of Mab $6 \mathrm{E}$ and focal adhesions. In formaldehyde-fixed chicken embryo fibroblasts, focal adhesions were detected with polyclonal anti-talin antibody $(\mathrm{A}, \mathrm{E})$ or with interference-reflection microscopy $(\mathrm{C})$. The corresponding images show filamentous actin stained with rhodamine-phalloidin (B) or the filamin isoform stained with Mab $6 \mathrm{E}(\mathrm{D}, \mathrm{F}) . \mathrm{Bars}, 10 \mu \mathrm{m}$ (A-D), $20 \mu \mathrm{m}(\mathrm{E}, \mathrm{F})$. 
precipitates from $\left[{ }^{35} \mathrm{~S}\right]$ methionine-labelled CEF quantitatively, using polyclonal anti-filamin antibody and Mab $6 \mathrm{E}$. Under conditions of antibody saturation, the Mab $6 \mathrm{E}$ isoform represented approximately $21 \pm 7 \%$ of the total

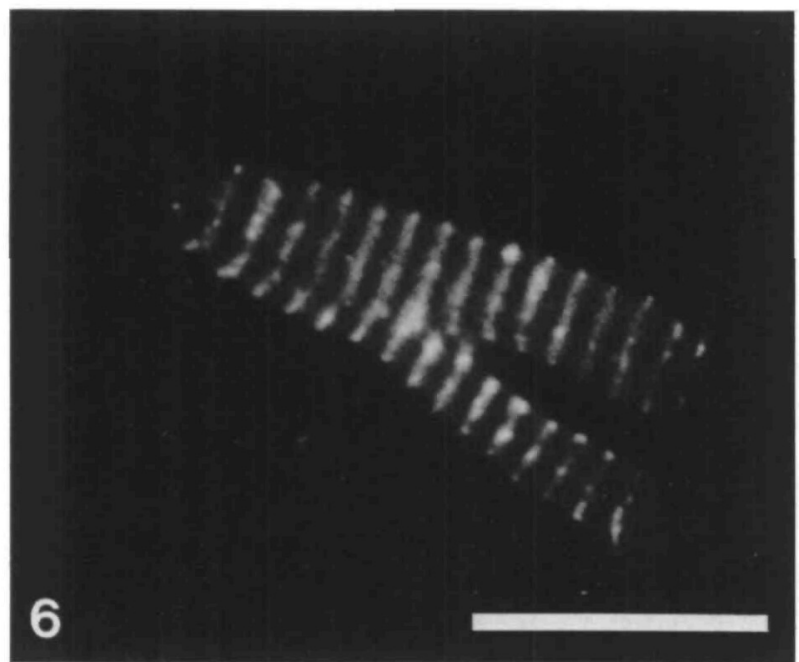

Fig. 6. Immunofluorescence staining of formaldehyde-fixed adult chicken myofibrils with Mab $6 \mathrm{E}$. Isolated myofibrils stained with Mab $6 \mathrm{E}$ were labelled in a striated pattern that corresponded to the Z-lines. Bar, $10 \mu \mathrm{m}$.

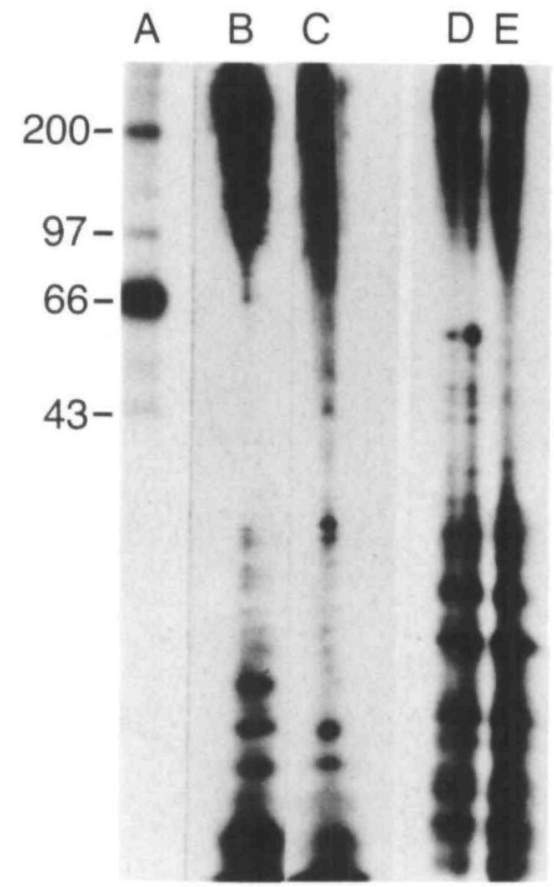

Fig. 7. Partial peptide maps of protein immunoprecipitated from $\left[{ }^{35} \mathrm{~S}\right]$ methionine-labelled chicken embryo fibroblasts using either a monoclonal antibody against filamin or Mab $6 \mathrm{E}$. Lane A, ${ }^{125} \mathrm{I}$-labelled molecular weight markers $\left(M_{\mathrm{r}} \times 10^{-3}\right)$. Lanes B-E, filamin (lanes B and D) or Mab $6 \mathrm{E}$ antigen (lanes $\mathrm{C}$ and $\mathrm{E}$ ) digested with either V8 protease (lanes B and C) or TPCK-trypsin (lanes D and E). Immunoprecipitated bands were excised from the first gel and treated with enzyme directly in the stacking portion of the $15 \%$ gel shown here, as described in Material and methods. filamin that could be precipitated by the polyclonal antibody.

\section{Discussion}

In this report we describe a monoclonal antibody (Mab $6 \mathrm{E})$ that labels the ends of stress fibers in chicken fibroblasts. The protein immunoprecipitated by this antibody cross-reacts with four distinct monoclonal antibodies against filamin as well as a polyclonal anti-filamin antibody. This indicates immunological homology with filamin. Partial peptide maps of the protein immunoprecipitated by this new monoclonal antibody also demonstrate that it is closely related to filamin. The unique peptides that were detected in these maps and the slight difference in apparent molecular weight of the intact protein suggest that, while similar, the $\mathrm{Mab} 6 \mathrm{E}$ antigen and the major form of filamin are not identical. The immunofluorescent localization in chicken embryo fibroblasts of the antigen recognized by $\mathrm{Mab} 6 \mathrm{E}$ was also distinct from the pattern that was obtained when cells were labelled with other monoclonal and polyclonal antifilamin antibodies. These results suggest that our new antibody recognizes a distinct isoform of the protein filamin that is concentrated at the ends of stress fibers in chicken fibroblasts.

Two actin-modulating functions have been ascribed to filamin. It is capable of cross-linking actin filaments into gels (reviewed by Weihing, 1985) and it is involved in linking actin to membrane glycoproteins in platelets (Fox, 1985; Okita et al. 1985; Ezzell et al. 1988). In platelets, a small amount of filamin (actin-binding protein) coprecipitates with the membrane glycoprotein complex Ib-IX. These results suggest that a subset of the filamin molecules in platelets may be involved in attachment of the actin cytoskeleton to the plasma membrane, while the majority of the filamin molecules fulfil the role of modulating actin filament organization. It remains to be determined if a similar situation exists in the chicken fibroblast.

With cytoskeletal proteins, differences in subcellular localization often correlate with differences in function. The Mab 6E antigen is more limited in its distribution than is the major form of filamin, and this pattern may reflect a specialized role for the $\mathrm{Mab} 6 \mathrm{E}$ isoform. The localization of the $\mathrm{Mab} 6 \mathrm{E}$ antigen near sites of actinmembrane attachment raises the possibility that this filamin isoform plays a role in linking actin to the membrane. Alternatively, it may be involved in stabilizing the lateral interactions between actin filaments at stress fiber ends. In order to investigate its function in cells, it will be necessary to determine the proteins with which the Mab $6 \mathrm{E}$ antigen interacts and to purify the $\mathrm{Mab} 6 \mathrm{E}$ antigen and compare its binding properties with those of other filamin isoforms.

The discovery of distinct muscle and non-muscle filamin isoforms (Gomer and Lazarides, 1983a,b) supports the notion that filamins have specialized roles in different cell types. Two forms of filamin with distinct peptide maps have also been found in $\mathrm{HeLa}$ cells 
(Mangeat and Burridge, 1983). These filamins were separated by their unique behavior on ion-exchange columns, yet they had similar actin cross-linking properties. It is not known if these two filamins exist in different locations in the cell, but the existence of filamins with different physical properties in a single cell type suggests that they may have specialized functions.

An unexpected result of our immunofluorescence experiments was the finding that, in fibroblasts, the Mab 6E antigen is found in a distribution that is very similar to that of $\alpha$-actinin. Both the Mab 6E and the $\alpha$-actinin staining overlap with focal adhesions but do not appear to fill the entire adhesion. This $\alpha$-actinin distribution is different from that seen in most mammalian cells where $\alpha$-actinin staining is more clearly periodic along stress fibers and is more prominently localized at their ends in focal adhesions.

Recently, Warren (1988) reported seeing a staining pattern in rat kidney cells with a monoclonal antibody specific for a low molecular weight isoform of tropomyosin that is similar to that seen with Mab 6E and anti- $\alpha$ actinin in chicken fibroblasts. Together, these results suggest that a number of cytoskeleton-associated protein isoforms may exist for a unique function near the plasma membrane. It is possible that these isoforms, being present in minor amounts, have previously been overlooked. The properties of the major isoforms, which are more easily assayed, may differ from the properties of minor isoforms. Our future efforts will be directed at separating filamin isoforms isolated from non-muscle cells to examine further the potential role that these proteins play in mediating cytoskeletal-membrane interactions.

We thank $\mathrm{Dr} \mathrm{J}$. Lin for the generous gift of monoclonal antibodies JLN10, JLN17, and JLN21 against filamin and Dr Karl Fath for critical reading of this manuscript. This work was supported by National Institutes of Health grants GM-29860 to K.B., a NIH National Research Service Award CA-08493 to F.M.P. and NCI Institutional Training Grant CA-09136, administered by the Lineberger Cancer Center to C.A.O.

\section{References}

BECHTEL, P. (1979). Identification of a high molecular weight actinbinding proten in skeletal muscle. F. biol. Chem 254, 1755-1758.

Burridge, K. \& ConNell, L. (1983). A new protein of adhesion plaques and ruffling membranes. F. Cell Biol. 97; 359-367.

Burridge, K., Fath, K., Kelly, T., Nuckolls, G. \& Turner, C. (1988). Focal adhesions: transmembrane junctions between the extracellular matrix and the cytoskeleton. A. Rev. Cell Biol. 4, 487-525.

BURriDGe, K. \& Feramisco, J. R. (1981). Non-muscle $\alpha$-actinıns are calcium-sensitive actın-binding proteins. Nature, Lond. 294, $565-567$.

Burridge, K. \& Mangeat, P. (1984). An interaction between vinculin and talin. Nature, Lond. 308, 744-746.

Cleveland, D. W. (1983). Peptide mapping in one dimension by limited proteolysis of SDS-solubilized proterns. Meth. Enzym. 96, 222-230.

Davies, P. J. A., Wallach, D., Willingham, M. C., Pastan, I., Yamaguchi, M. \& Robson, R. M. (1978). Filamın-actin interaction: dissociation of binding from gelation by calciumactivated proteolysis. 7. biol. Chem. 253, 4036-4042.

Ezzell, R. M., Kenney, D. M., Egan, S., Stossel, T. P. \&
HARTWG, J. H. (1988). Localization of the domain of actinbindıng protein that binds to membrane glycoprotein $\mathrm{Ib}$ and actın in human platelets. F. biol. Chem. 263, 13303-13 309.

Feramisco, J. R. \& BURRIDGe, K. (1980). A rapid purification of $\alpha$ actinin, filamin, and a 130,000-dalton protein from smooth muscle 7. biol. Chem. 255, 1194-1199.

Fox, J. E. B. (1985). Identification of actin-binding protein as the protein linking the membrane skeleton to glycoproteins on platelet plasma membranes. F. biol. Chem. 260, 11 970-11977.

GEIGER, B. (1979). A 130K proten from chicken gizzard: its localization at the termini of microfilament bundles in cultured chicken cells. Cell 18, 193-205.

Gomer, R. H. \& Lazarides, E. (1981). The synthesis and deployment of filamin in chicken skeletal muscle. Cell 23, 524-532. GOMER, R. H. \& LAZARIDEs, E. (1983a). Switching of filamin polypeptides during myogenesis in vitro. F. Cell Biol. 96, 321-329.

Gomer, R. H. \& LAZARIDES, E. (1983b). Highly homologous filamin polypeptides have different distributions in avian slow and fast muscle fibers. \%. Cell Biol. 97, 818-823.

GoRDON, W. E. III (1978). Immunofluorescent and ultrastructural studies of "sarcomeric" units in stress fibers of cultured non-muscle cells. Expl Cell Res. 117, 253-260.

Gordon, W. E. III \& BusHNell, A. (1979). Immunofluorescent and ultrastructural studies of polygonal microfilament networks in respreading non-muscle cells. Expl Cell Res. 120, 335-348.

HarTwiG, J. H. \& Stossel, T. P. (1975). Isolation and properties of actın, myosin and a new actın-binding proten in rabbit alveolar macrophages. F. biol. Chem. 250, 5696-5705.

Heggeness, M. H., WaNG, K. \& Singer, S. J. (1977). Intracellular distributions of mechanochemical proteins in cultured fibroblasts. Proc. natn. Acad. Sci. U.S.A. 74, 3883-3887.

HoCk, R. S. \& CoNDEELIS, J. S. (1987). Isolation of a 240-kılodalton actin-bınding protein from Dictyostelium discoideum. F. biol Chem. 262, 394-400.

Horwitz, A., Duggan, K., Buck, C., Beckerle, M. C. \& BURRIDGE, K. (1986). Interactions of plasma membrane fibronectin receptor with talin - a transmembrane linkage. Nature, Lond. 320, 531-533.

IzZARD, C. S. \& LOCHNER, L. (1976). Cell-to-substrate contacts in cultured chick embryonic cells: an interference reflection study. $\mathcal{J}$. Cell Sci. 42, 81-116.

LaEmmu, U. K. (1970). Cleavage of structural protens during the assembly of the head of bacteriophage T4. Nature, Lond. 227, 680-685.

Langanger, G., DeMey, J., Moeremans, M., Daneels, G., DeBrabander, M. \& SmaLL, J. V. (1984). Ultrastructural localization of $\alpha$-actinin and filamin in cultured cells with the immunogold staining (IGS) method. F. Cell Biol. 99, 1324-1334.

LAZARIDES, E. (1975). Tropomyosin antibody: the specific localization of tropomyosin in nonmuscle cells. J. Cell Biol. 65, $549-561$.

LAZARIDES, E. \& BURRIDGE, K. (1975). $\alpha$-actinin: immunofluorescent localization of a muscle structural protein in nonmuscle cells. Cell 6, 289-298.

Lucas, R. C., Gallagher, M. \& Stracher, A. (1976). Actin and actin-bindıng protein in platelets. In Contractile Systems in NonMuscle Tissues (ed. S. V. Perry), pp. 133-139. Amsterdam: Elsevier, North-Holland Publishing Co.

Mangeat, P. \& Burridge, K. (1983). Binding of HeLa spectrin to a specific HeLa membrane fraction. Cell Motil. 3, 657-669.

MaRUYama, K. \& EBASHI, S. (1965). $\alpha$-actinin, a new structural protein from strated muscle. II. Action on actin. 7 . Biochem. (Tokyo) 58, 13-19.

Miller, K. G., Karr, T. L., Kellogg, D. R., Mohr, I. J., Walter, M. \& ALberTS, B. M. (1985). Studies on the cytoplasmic organization of early Drosophila embryos. Cold Spring Harb. Symp. quant. Biol. 50, 79-90.

Oktta, J. R., Pidard, D., Newman, P. J., Montgomery, R. R. \& KUNICKI, T. J. (1985). On the association of glycoprotein Ib and actin-bindıng protein in human platelets. F. Cell Biol. 100 317-321.

OSBORN, M. \& WeBer, K. (1979). Microfilament-associated proteins in tissue culture cells viewed by stereo immunofluorescence microscopy. Eur. F. Cell Biol. 20, 28-36. 
OTTO, J. J. (1983). Detection of vinculin-binding proteins with an 125 I-vinculin gel overlay technique. F. Cell Biol. 97, 1283-1287.

Rathke, P. C., Osborn, M. \& Weber, K. (1979). Immunological and ultrastructural characterization of microfilament bundles: polygonai nets and stress fibers in an established cell line. Eur. J. Cell Biol. 19, 40-48.

Sanger, J. W., Sanger, J. M. \& Jockusch, B. M. (1983)

Differences in the stress fibers between fibroblasts and epithelial cells. J. Cell Biol. 96, 961-969.

Stossel, T. P., Chaponnier, R. M., Ezzell, R. M., Hartwig, J. H., JaNMEY, P. J. et al. (1985). Nonmuscle actin-binding proteins. A. Rev. Cell Biol. 1, 353-402.

Towbin, H., Staehelin, T. \& Gordon, J. (1979). Electrophoretic transfer of proteins from polyacrylamide gels to nitrocellulose sheets: procedure and some applications. Proc. natn. Acad. Sci. U.S.A. 76, 4350-4354.

Wachsstock, D. H., Wilkins, J. A. \& LiN, S. (1987). Specific interaction of vinculin with $\alpha$-actınin. Biochem. biophys. Res. Commun. 146, 554-560.

Wallach, D., Davies, P. J. A. \& Pastan, I. (1978). Cyclic AMPdependent phosphorylation of filamin in mammalian smooth muscle. J. biol Chem. 253, 4739-4745.

WANG, K., ASH, J. F. \& Singer, S. J. (1975). Filamin, a new highmolecular-weight protein found in smooth muscle and non-muscle cells. Proc. natn. Acad. Sci. U.S.A. 72, 4483-4486.
WARREN, R. H. (1988). Localization of tropomyosin isoforms in rat kidney cells. 7. Cell Biol. 107, 680a.

WEBSTER, R. E., OsBorN, M. \& WEBER, K. (1978). Visualization of the same PtK2 cytoskeletons by both immunofluorescence and low power electron microscopy. Expl Cell Res. 117, 47-61

Wehland, J., Osborn, M. \& Weber, K. (1979). Cell-to-substratum contacts in living cells: A direct correlation between interferencereflection and indirect-immunofluorescence microscopy using antıbodies against actın and $\alpha$-actinin. 7. Cell Sci. 37, 257-273.

WEIHING, R. R. (1983). Purification of HeLa cell high molecular weight actın binding proteın and its identification in HeLa cell plasma membrane ghosts and intact HeLa cells. Biochemistry 22, $1839-1847$.

WeirIng, R. R. (1985). The filamins: properties and functions. Can. 7. Biochem. Cell Biol. 63, 397-413.

WILkINS, J. A., Chen, K. Y. \& LIN, S. (1983). Detection of high molecular weight vinculin bindıng proteins in muscle and nonmuscle tissues with an electroblot-overlay technique. Biochem. biophys. Res. Commun. 116, 1026-1032.

Zigmond, S. H., OtTo, J. J. \& BRYAN, J. (1979). Organization of myosin in a submembranous sheath in well-spread human fibroblasts. Expl Cell Res. 119, 205-219.

(Received 26 April 1989 - Accepted 2 June 1989) 